\title{
Non-destructive Testing of Split Sleeve Welds by the Ultrasonic TOFD Method
}

\author{
Marek Patek ${ }^{1}$, Radoslav Konar ${ }^{1}$, Augustin Sladek ${ }^{1}$, Norbert Radek ${ }^{2}$ \\ ${ }^{1}$ Department of Technological Engineering, Faculty of Mechanical Engineering, University of Žilina, Univerzitna 8215/1, \\ 01026 Žilina. Slovak Republic. E-mail: marek.patek@fstroj.uniza.sk. \\ ${ }^{2}$ The Centre for Laser Technologies of Metals, Kielce University of Technology. 25-314 Kielce. Poland. E-mail: \\ norrad@tu.kielce.pl
}

This article deals with the non-destructive ultrasonic testing of split sleeve butt joints by ultrasonic methods. Split sleeve is used to repair gas pipelines with gas leakage. The new ultrasonic methods TOFD and Phased Arrays are compared considering to the selected butt weld configuration. To compare testing methods, ES Beam Tool software was used to prediction of ultrasonic beam spread through weld joint. TOFD technology was selected to butt weld section testing according to the beam spread simulation results. The results of ultrasonic testing by TOFD method were compared with results of macrostructural analysis of weld joint. Controlling the suitability of testing method to planar defect identification, the artificial defects were prepared and tested. The appropriate setting of measuring technique can be predicted from experimental results.

Keywords: Ultrasonic testing, TOFD, Split Sleeve, Defects

\section{Acknowledgement}

The article has been created within the framework of VaV task assigned by SPP-D Company, also nr. 561/PG04/2011 supported by uninvesting fund EkoFond, which founder is company SPP, a.s. and by SPP-D Company. This paper has been arisen also thanks to supply of grant project VEGA-1/0547/11, KEGA-039ŽU-4/2011.

\section{References}

[1] MICIAN, M., PATEK, M., SLADEK, A. (2014). Concept of repairing branch pipes on high-pressure pipelines by using split sleeve. In: Manufacturing Technology, Vol. 14, No. 1, pp. 60-66. Faculty of Production Technology and Management, Usti n. Labem, CR.

[2] PRAVEEN, A., VIJAYAREKHA, K., ABRAHAM, S.T., VENKATRAMAN, B. (2013). Signal quality enhancement using higher order wavelets for ultrasonic TOFD signals from austenitic stainless steel welds. In: Ultrasonics, Vol. 53, pp. 1288-1292. Elsevier, Philadelphia, USA.

[3] MERAZI-MEKSEN, T., BOUDRAA, M., BOUDRAA, B. (2014). Mathematical morphology for TOFD image analysis and automatic crack detection. In: Ultrasonics, Vol. 54, pp. 1642-1648. Elsevier, Philadelphia, USA.

[4] FERRAND, A., DARMON, M., CHATILlON, S., DESCHAMPS, M. (2014). Modelling of ray paths of head waves on irregular interfaces in TOFD inspection for NDE. In: Ultrasonics, Vol. 54, pp. 1851-1860. Elsevier, Philadelphia, USA.

[5] DUBE, N. (2004). Introduction to Phased Array Ultrasonic Technology Applications: R/D Tech Guideline, pp. 910. Olympus NDT, Waltham, USA.

[6] DOPJERA, D., MIČIAN, M. (2014). The Detection of Artificially Made Defects in Welded Joint with Ultrasonic Defectoscopy Phased Array. In: Manufacturing Technology, Vol. 14, No. 1, pp. 12-17. Faculty of Production Technology and Management, Usti n. Labem, CR.

[7] DOPJERA, D., MICIAN, M., SLADEK, A. (2013). Phased Array System for non destructive testing in the industry. In: Advanced manufacturing and repairing technologies in vehicle industry: $30^{\text {th }}$ international colloquium, $\mathrm{pp}$. 103-110, BME, Budapest, Hungary.

[8] KOŇÁR, R., MIČIAN, M. (2014). Non-destructive Testing of Welds in Gas Pipelines Repairs with Phased Array Ultrasonic Technique. In: Manufacturing Technology, Vol. 14, No. 1, pp. 42-47. Faculty of Production Technology and Management, Usti n. Labem, CR.

[9] ZMINDAK, M., MESKO, J., PELAGIC, Z., ZRAK, A. (2014). Finite Element Analysis of Crack Growth in Pipelines. In: Manufacturing Technology, Vol. 14, No. 1, pp. 116-122. Faculty of Production Technology and Management, Usti n. Labem, CR.

[10] CEP, R., JANASEK, A., CEPOVA, L., HLAVATY, I., et al. (2013). Experimental testing of exchangeable cutting inserts cutting ability. In: Tehnicki Vjestnik-Technical Gazette, Vol. 20, No. 1, pp. 21-26. 
[11] MOHYLA, P., TOMCIK, P., BENES, L., HLAVATY, I., et al. (2011). Effect of post-welding heat treatment on secondary hardening of welded joints of Cr-Mo-V steel. In: Metal Science and Heat Treatment, Vol. 53, No. 7-8, pp. 374-378.

[12] NOVAK, P., MESKO, J., ZMINDAK, M. (2013). Finite element implementation of Multi-pass Fillet Weld with Phase Changes. In: Manufacturing Technology, Vol. 13, No. 1, pp. 79-85. Faculty of Production Technology and Management, Usti n. Labem, CR.

\section{Paper number: M201474}

Copyright (C) 2014. Published by Manufacturing Technology. All rights reserved. 